Article

\title{
From Eco-Civilization to City Branding: A Neo-Marxist Perspective of Sustainable Urbanization in China
}

\author{
Martin de Jong ${ }^{1,2}$ \\ 1 Erasmus School of Law \& Rotterdam School of Management, Erasmus University Rotterdam, Postbus 1738, \\ 3000 DR Rotterdam, The Netherlands; w.m.jong@law.eur.nl \\ 2 School of International Relations and Public Affairs, Fudan University, Shanghai 200433, China
}

Received: 26 June 2019; Accepted: 25 September 2019; Published: 12 October 2019

check for updates

\begin{abstract}
While the national discourse on 'eco-civilization' drives conceptual thinking on sustainable urban development in China, in practice a systematic implementation gap appears to exist when it comes to local implementation. This paper examines how the leakage occurring in the trajectory from central government ideas to municipal and district level construction projects can be explained. More specifically, it aims to spot whether it is merely the result of mismatches resulting from ineffective interactions among players in the policy process, institutional misalignment between policy goals and policy instruments, or even if the mobilization of bias in the policy process is systematic enough to justify a neo-Marxist explanation of the abovementioned implementation gap. I found two main sources of structural bias: capital accumulation in the mechanisms for urban development and power accumulation in the mechanisms underlying the administrative process.
\end{abstract}

Keywords: eco-civilization; city branding; neo-Marxism; mobilization of bias; capital accumulation; power accumulation; China

\section{Introduction}

In response to serious environmental deterioration and the wish to play a leading role worldwide in countering climate change, the Chinese government has introduced a new policy discourse accompanied by a number of new policy initiatives in recent years. A prominent concept for the direction in which the Chinese economy and society should evolve is that of building an 'eco-civilization' [1]. Although this may evoke a faint idea of living in harmony with nature or even a Daoist impression of living a simple natural life-style [2], what an 'eco-civilization' entails in practice has been largely undefined [3]. Another significant and attractive new concept is that of 'new-type urbanization' [4,5], with which China's central government proclaims that future construction of new towns and upkeep of existing urban areas should be done in a more environmentally friendly manner and with stronger local stakeholder involvement.

One may expect these high-brow ambitions expressed at the central level, concretized or not, to be echoed at the lower levels of the Chinese administrative hierarchy, such as among municipalities and districts; and they are. The country now counts hundreds of eco cities, low carbon cities, low carbon eco cities, sponge cities, and smart cities. These all reflect, in one way or another, the wish to make buildings greener, transport systems more sustainable, technologies cleaner and industrial parks more circular. However, when it comes to effective policy implementation, serious doubt has emerged on the extent to which the proclaimed deep urban transformation is actually occurring. Various scholars have highlighted in recent work on sustainable urban development in China the existence of a systematic 'implementation gap' [6-9]. 
Viewing urban planning processes through the lens of the policy sciences, a complex of administrative incentives and mechanisms can be 'held responsible' for this deficit in policy effectiveness. Following that line of reasoning, I may argue that this hinges on different policy actors having different interests, embracing different objectives, and controlling different policy resources or instruments required to effectuate a policy. Successful policy implementation obliges these actors to engage in forms of collaboration leading to a package deal in which these resources are deployed and pooled in particular ways conducive to societal problem solving. In many cases, no such workable and constructive compromises are generated during and after interaction, because actors are unable or unwilling to produce them $[10,11]$. Such circumstances make it less probable that the sustainable cities which the Chinese national government envisages and local governments state they construct truly physically come about. Consequently, looking at sustainable urban development from the bottom up, a far more fragile picture of implementing attractive concepts and goals in complex and dynamic policy networks emerges. While pinpointing impasses in policy processes and clarifying reasons for implementation deficits as they emerge, policy scientists also offer remedies such as having constructive dialogues among actors, anticipating implementation difficulties by involving stakeholders upfront in the policy formulation phase, taking the stakes and perceptions of various actors seriously and even changing the institutional rules of the game if that is beneficial for improved patterns of interaction. These suggestions, mutatis mutandis, apply to planning and policy making in China as they do to the rest of the world $[9,12,13]$.

Most scholars in public policy appear satisfied with offering policy recommendations in the sphere of improved interaction among policy actors involved in policy-making (at the level of policy actors) or adaptations in the regulatory framework and cultural patterns structuring interaction among them (at the level of institutions). However, those who tend to dive 'deeper' than (1) interaction among policy actors or (2) institutional rules for behavior, point at the presence of (3) structural forces underlying the emergence of these institutional rules and policy interactions [14]. They would argue that systematic and lasting imbalances can be observed in the positions that various socio-economic strata, classes, and groups occupy in society. Systematic inequality among these groups in their ability to influence the evolution of institutional rules and the admission of political problems onto the policy agenda leads to a so-called 'mobilization of bias' [15]. If this bias is structural, policy-making can be expected overwhelmingly to serve the interests of dominant strata or classes in society [16-18]. If it is not structural but incidental and the policy process is open to various players and over time balances the interests of various societal groups, aggregate outcomes churned out by an administrative system can be seen as more egalitarian and are called 'polyarchic' [19]. The former situation would be a strong argument in favor of elitism (a relatively small coterie of people in society wields disproportionate amounts of power and this is reflected at the institutional and interactional levels) or even neo-Marxism (if a capitalist class is seen as holding most or all of this structural power), the latter situation is in favor of pluralism (input to the policy process comes from various sides with different groups winning negotiations at different moments and outcomes depending more on skillful play than on privileged positions).

In politico-administrative systems where democracy, rule of law, political and legal freedom, checks and balances, and other forms of fragmentation and power distribution exist, the a priori credibility of adopting pluralist views seems higher, although the validity of a neo-Marxist perspective in Western countries is also argued by some policy scientists and many geographers and planning theorists [20-22]. In this contribution, I aim to throw light on the position of China's administrative system, itself originally inspired by Marxist principles, and the impact it has on sustainable urban development. Answering that question will help understand how general discursive principles and visionary objectives in Beijing are translated into effective action in China's heartlands and which societal groups benefit from that process and its outcomes. I will examine the interactive and institutional mechanisms through which the Chinese national discourse on sustainable urbanization is converted into policy implementation at the local level and what role structural forces play in this 
process. I will not be deploying the whole range of neo-Marxist terminology; specific focus will lie on the concepts 'capital accumulation' and 'power accumulation' and on the question whether and how these processes of exploitation take place (1) through the regulation of land ownership and control as a factor of production and (2) through the allocation of politico-administrative positions. This implies that other production factors such as labor and other economic sectors remain outside the scope of this contribution.

The analysis will be undertaken in the following steps:

In Section 2, the new discourse on ecological civilization and new-type urbanization policy initiated by the central government in Beijing will be introduced, along with dominant patterns in sustainable urban development and city branding as practiced by local governments around the country. The branding practice described here deviates substantially from the precept developed in the academic literature [23-25] in that it resembles green washing more than deployed efforts for profound urban transformation.

Section 3 will portray the main institutional mechanisms underlying the implementation of sustainable urban planning in China and explain what mobilization of bias can be observed in them. Based on that test, I will argue that these mechanisms open doors to extensive capital accumulation.

Section 4 will then dissect the institutional mechanisms embedded in China's political and administrative system, describe which role the party and the state play in it, and what intergovernmental relations look like. Based on that dissection, I will argue that these mechanisms represent a fair amount of power accumulation.

In concluding Section 5, I will then examine the validity of a neo-Marxist approach to explaining sustainable urbanization in China and verify whether the combination of both types of mobilization of bias can be interpreted as one that is in fact steered by structural forces that go beyond mere interaction among policy actors or mere unbalance in policy input explained by institutional rules of the game. Can the conversion of lofty ideologically framed discourses on ecological civilization into their eventual fleshing out into the construction of average residential areas and industrial parks in new towns in China be understood as a mix of capital accumulation and power accumulation occurring in the process of planning and implementing sustainable urban development?

\section{From Eco-Civilization to City Branding}

The term 'ecological civilization' first appeared in 2007, in the report of the 17th National Congress of the Communist Party of China (CPC) [26]. Five years later, in 2012, the Chinese state confirmed its strong commitment to the concept by officially adopting it in the CPC charter at the 18th National Congress. In addition, the national government incorporated 'ecological civilization' under the Five in One overall development strategies, which encompassed economy, politics, culture, society, and eco-civilization [27]. In 2015, the Integrated Reform Plan for Promoting Ecological Progress was released, the first policy document explicitly addressing the concept. It was aimed at 'building a beautiful China' and forming 'a new pattern of modernization in which human beings live in harmony with nature' [28]. In 2016, 'ecological civilization' was also embraced in the 13th Five-Year Socio-Economic Plan; more specifically, the term 'Green Development' was introduced. There it was claimed that in the period 2016-2020, it was the government's top priority to promote innovative, coordinated, green, open, and shared development [29]. In 2017, President Xi personally stated the importance of ecological civilization in the report of the 19th National Congress of the CPC. Section IX of this report, entitled Speeding up Reform of the System for Developing an Ecological Civilization, and Building a Beautiful China, listed four commitments: (1) promoting green development, (2) solving prominent environment problems, (3) intensifying the protection of ecosystems, and (4) reforming the environmental regulation systems [30]. In 2018, ecological civilization found its place inside the Constitution of the People's Republic of China, an unprecedented development in the history of environmental governance in China [31]. Table 1 presents a chronological overview of these milestone events. 
Table 1. The timeline of the ecological civilization in China.

\begin{tabular}{cl}
\hline Year & \multicolumn{1}{c}{ Key Event } \\
\hline 2007 & The concept 'ecological civilization' first appears at the 17th National Congress \\
2012 & 'Ecological civilization' is adopted by the CPC charter at the 18th National Congress \\
2015 & An integrated Reform Plan for Promoting Ecological Progress is released \\
2016 & 'Ecological Civilization' is embraced in the 13th Five-Year socio-economic Plan \\
2017 & Section IX of the 19th National Congress report exclusively focuses on ecological civilization \\
2018 & Ecological civilization is written into China's Constitution \\
\hline
\end{tabular}

In the past decades, China has experienced rapid urbanization and by 2017, urban residents constituted $58.5 \%$ of its total population [32]. Urbanization has exacerbated various environmental challenges, including air and water pollution, growing amounts of waste, and loss of agricultural land and fertility. In 2014, the Chinese government launched its national New-Type Urbanization Plan (2014-2020). Distinct from previous patterns of urbanization, New-Type Urbanization emphasizes a people-centered and environmentally friendly pathway to urban expansion. The plan points out that 'ecological civilization' should be fully embedded in the process of New-Type Urbanization and, more generally, that green, circular, and low-carbon development should be strongly promoted. In Chapter 18 of the plan, green urban development is highlighted with the domains of green energy, green building, green transportation, circular development at industrial parks, integrated urban pollution treatment, and green lifestyles and actions all explicitly mentioned [33]. Against that backdrop, it is not surprising that various scholars argue that the New-Type Urbanization is de facto one of the instruments and carriers of the ecological civilization construction in China $[34,35]$. Empirical studies have shown that as a policy approach it has indeed inspired some forward-looking municipalities to engage in more participatory processes of policy-making, to pay more heed to preserving cultural heritage and to favor environmentally friendly interventions [4,36,37].

Another concretization of promoting ecological civilization can be seen in the adoption of a variety of sustainable city programs among national committees and ministries. The National Development and Reform Committee (NDRC), the Ministry of Housing and Urban Rural Development (MOHURD), and the Ministry of Ecology and Environment (MEE) have all enacted policy programs that encourage provinces, municipalities, and districts to volunteer as demonstration or pilot cities in sustainable urbanization. They have invited local governments to draft and submit urban development projects going by the name of 'eco city', 'low carbon city', 'low carbon eco city', 'sponge city', or 'smart city', which in one way or another engage with the societal vision and policy objectives expressed in ecological civilization and new-type urbanization [7,38-46]. The latter have massively responded to these programs by writing proposals in which they designate their new town projects as any of these sustainable city labels and submitting these to the respective national body responsible for the specific program they opted for. NDRC, MOHURD, and MEE at their turn have selected the most promising proposals and placed them on their official lists of formally recognized eco cities, low carbon cities, low carbon eco cities, sponge cities, and smart cities. Local governments can expect policy support from them in exchange for regular progress reports pointing out their scores on categories of key performance indicators relevant to social, economic, and ecological sustainability. Being allowed to use these recognized sustainable city labels encourages local governments to engage in positive action, but also serve as a useful marketing instrument for the attraction of investors, companies, talented residents, and visitors that can add significantly to both local revenue and nominal GDP growth. Hundreds of such submissions have been endorsed, making the Chinese appearance in sustainable urban development a truly impressive one from a cross-national comparative perspective [47-53]. In fact, the attractiveness of these labels in the midst of a reality of severe pollution and health risk is such that there are definite advantages even for municipalities whose proposals were not approved still to make use of these labels. 
Empirical evidence is beginning to pile up that only few of them deliver the new town projects or industrial parks which the central government intended when the national programs were launched. Only in some cases are sustainable city indicator systems which monitor performance really established, and in even fewer cases is that performance systematically monitored. The latter is mostly the case when broad international visibility of a sustainable city project obliges authorities to produce systematic reports to justify their interventions, such as with Sino-Singaporean Tianjin Eco City, Shenzhen International Low Carbon City, and Chongming International Eco Island $[46,54,55]$. A closer investigation of the policy networks generally involved in sustainable city development has shown that in order to make these urban development projects successful, resources from the national government play a minor role. Rather is it the case that local governments need funding resources from real estate development to complement their municipal expenditure on public services to their broader urban community, which they derive from project developers and not from the central government. Practically speaking, therefore, their dependency on the local private sector largely exceeds that on the national committees and ministries which formally endorse their eco, low carbon, or smart stigma $[7,9]$. In effect, then, the eco label remains highly desirable, but more as a token of greenness to the world of investors, corporations, new inhabitants, and tourists than for the implementation of an eco-civilization agenda. This outcome presents an obvious risk of a sustainable urbanization branding practice degenerating into green-washing rather than actual eco-transformation [56].

\section{Mobilization of Bias I: Capital Accumulation in Sustainable Urban Planning}

Urbanization in China began considerably later than in most developed countries, but once it gained steam, it occurred remarkably fast and its impact has been pervasive in recent years. To absorb the massive influx of people moving from rural into urban areas, all cities of any importance, and especially those located along the Eastern shore of the country, develop large-scale new town projects [57]. These new towns often consist of large residential areas with high-rise buildings at various quality and price levels and burgeoning (industrial) science and technology parks where newly establishing and relocating companies can be hosted. Especially in the past decade when the optimistic mood of exuberant economic growth levels was increasingly accompanied by the ghastly emergence of unprecedented levels of water, soil, and air pollution, the urge to make these new towns cleaner and greener has grown continuously [58]. What exactly 'green', 'sustainable', or 'eco' entails and what it takes to build it is commonly not clearly defined, neither in China nor anywhere else in the world, but various national ministries have adopted special programs for the adoption of demonstration cities in sustainable urban development or pilot projects in ecological industrial parks $[7,9,43,59]$. Cities and high-tech parks participating in these national programs commit themselves to the quality standards and procedures formulated in these programs and report on their progress in sustainable building on a regular basis. This has led a great many cities and industrial parks to label themselves as sustainable, green, eco, low carbon, circular, etc., and pride themselves in these denominations. In fact, even those cities that did not succeed in or even aim for obtaining such an official status still adopt similar terms to describe their development projects [6]. This is not surprising in light of the fact that considerations of environmental quality have risen rapidly in the pecking order of priorities for the wealthy and highly talented residents and employees that cities and industrial parks wish to attract for their self-upgrade from old-fashioned manufacturing town to modern service-industry driven metropolis. Not all cities and within cities not all districts can realize this Chinese dream. Those which are attractively located, have the easiest access to central areas and central business districts, and pride themselves in the hospitals and schools of the highest repute have by far the easiest time in getting off the ground [60]. However, since they all share this dream, the actual value which official labels for cities, parks, districts, and projects at any place have cannot be taken for granted in terms of how 'green or sustainable they truly are'. There is no shortage of studies indicating that even the best eco cities in China are not true 'eco cities', that the close collaboration between municipal governments and project developers leads to oversupply of residential areas and high tech parks ('ghost towns') and that urban expansion into 
formerly rural areas without concomitant supply of high-quality transport facilities have led to less than perfect solutions for pressing urbanization and ecological problems [61,62]. However, it is also indisputable that compared with many other places in the world, policy attempts to reduce further deterioration of the natural environment and carbon dioxide emissions, efforts made in constructing infinite numbers of new buildings of average to high quality and the speed with which high speed rail and urban metro systems have emerged in the past decades are all unprecedented. None of this is likely to be repeated any time soon anywhere else in the world. Even if China's ecological footprint continues to rise and economic growth has tapered off, the allocation of physical and financial resources in its urbanization process has been truly impressive.

However, along with economic allocation come distribution issues. It is here that serious pain becomes apparent with a growing gap in capital and income across various groups in Chinese society. China's urbanization process has contributed in a major way to this mounting inequality [63]. Many of the new towns appear in more peripheral zones of cities, often even in areas which were previously or still used as rural land. As is usual in Communist countries, land cannot be privately owned. According to the Land Administration Law, urban land is state-owned and rural land is collectively owned. Only state-owned land would be used for urban development, therefore in the urbanization process, large amounts of rural land have been and are converted to urban land. Rural collectivities are legally obliged to sell this land to municipalities instead of private buyers, thus seeing their options to obtain a good market price for it severely restricted [64]. After the transfer of this land at a low price to local governments (county/city level), the latter make it ready for construction and lease it to developers for a far higher amount, which is called a land conveyance fee. Such fees largely contribute to local fiscal revenues $[65,66]$. These developers in turn put a premium on constructing high-rise buildings and/or offices at moderate costs and sell or let the apartments in them at high prices to incoming home owners and tenants or new companies occupying factories and offices [67]. In popular neighborhoods of leading cities, this has led to the sky-rocketing of real estate prices, while construction projects far out of the center with limited accessibility are often short of buyers or used for speculation purposes rather than full-time occupancy. Since many developers are state-owned enterprises and/or huge in scale and turnover, their risk of going bankrupt from erroneous investments is minimal. In this process, local governments and project developers emerge as outright winners [66]. Cities earn money from land transfer that can be used to fill the municipal coffers and they can report good GDP growth figures to their superiors at the provincial and national level since real estate is a substantial share of urban economic (nominal) growth. Developers in turn are enabled to take on real estate development projects at astronomical financial scales all around the country and their turnover and profit levels tend to dwarf those anywhere else in the world.

The critical literature in urban studies would reserve a well-known name for this alliance and name it the existence of 'Urban Growth Coalitions' or 'Urban Growth Machines' [68]. Still, there is a catch. Since 1994's tax reform, local governments in China have had to transfer a far bigger share of their tax income to the central government than before and have therefore been practically obliged to generate much of their revenue by issuing land. The share of municipal tax income derived from real estate development varies but easily reaches $50 \%$ in most of them $[7,66]$. This implies that central government offices and a limited number of bureaucrats and party-officials in high positions there have become comparatively wealthier $[69,70]$. Likewise, the group of developers who often enjoy nation-wide rather than just local presence is fairly small [71]. In addition, another large share of the loss in capital incurred by rural communities through land expropriation is indirectly spent on the delivery of local government services to urbanites who were already much better off than their rural compatriots anyhow. Meanwhile, prosperity levels in the countryside do not rise nearly as fast as in the cities. The urban poor have generally not fared well either. Some among them are migrant workers not entitled access to urban welfare and services in cities where they work because they do not have the local non-agricultural 'hukou' [72]. With agricultural hukou, migrants are only entitled to rural social welfare in their sending villages $[73,74]$. Others are urban residents who did obtain 
non-agricultural 'hukou' and therefore this entitlement to municipal services. In some cases, such urban residents are allocated an apartment in the urban periphery as a result of their rural housing and/or land expropriation. Most of these urban poor have rarely seen noticeable growth in their annual incomes although in some megacities, the compensation for such expropriation is regarded a windfall profit for households [75]. It is worth noting that final individual outcomes in fortune heavily depend on how tactically skilled and flexibly they acted and how lucky they were in dealing with governments and developers during their negotiations before their eviction [57].

Given the above, it is not far-fetched to see China's urbanization, as some scholars do, as a powerful process of capital accumulation in which high financial value in land previously collectively owned by farmers is indirectly transferred to upper-class families controlling real estate empires and middle class families enjoying generous urban services within their well-off municipalities [68,76]. The losers are in the first place the originally rural families who have been offered cheap or even free apartments and access to municipal public services to which they previously did not have access. In many cases, however, the actual capital value of these new benefits is only a fraction of what they lost due to the transfer. The second group of losers is constituted by migrant workers offering labor services in the cities where they are employed for manual jobs but where they have no legal access to essential entitlements which would secure them and their offspring a better future, such as healthcare and education.

\section{Mobilization of Bias II: Power Accumulation in Sustainable Politics and Policy}

China's political and administrative system is, as can be guessed, in essence of Soviet origin [77]. The state, in spite of leading a country with the size of a continent and having a population of 1.4 billion people, is still a unitary one. The central government is officially in the lead, with provincial, municipal, and district governments following in its wake and implementing the laws, plans, and programs initiated by Beijing on a more detailed level. Equally importantly, since the People's Republic of China is in practice a one-party state (a number of approved token satellite parties notwithstanding), the Communist Party of China provides the ideological direction and fervor behind policies of which the government is considered the operational arm [77,78]. Put differently, the crucial guidance and general ideas are generated by the CCP and the government bureaucracies provide the practical follow-up. This is true at all government tiers: nation, province, municipality, and district (for urban areas) or county (for rural areas). Many key positions in both the party and the government hierarchy are occupied by the same people who therefore have both busy schedules and enormous amounts of power. This osmosis of party and government leads to high levels of power concentration among small numbers of individuals at the apex of party organizations and government bureaucracies $[79,80]$.

An effective way to secure compliance with central guidance among the lower ranks is through the nomenclature system of promoting government officials [81,82]. High-level officials at the district, municipal, provincial, and national tiers of government are not chosen by an electorate but evaluated through an official assessment system administered from above. In this a variety of indicators play a role, of which growth of Gross Domestic Product, avoiding riots and revolts, some environmental norms and, increasingly, demonstrated loyalty to the leadership play key roles $[83,84]$. This evaluation is partly objectified, but it has been shown to have a variety of weaknesses including responsibility borne for duties that cannot be practically fulfilled and political (ab)use [85].

This constellation of factors and actors is reflected in the way sustainable urbanization is fleshed out as a policy to be implemented in the politico-administrative complex. Based on crucial discursive concepts such as ecological civilization and new type urbanization coined by the CCP leaders in a number of speeches, statements, reports and eventually the constitution, committees, and ministries under the State Council (China's government council) such as the National Development and Reform Committee (NDRC), the Ministry of Housing and Urban-Rural Development (MOHURD), Ministry of Ecology and Environment (MEE) and the Ministry of Natural Resources draft long-term plans for their respective policy area, which are subsequently replicated and further detailed by the provincial, 
municipal, and district governments below them. In addition to that, most of these committees and ministries also issue their own sustainable city demonstration programs for which volunteers among local governments can apply. Although the administrative structure is hierarchical in concept and formal structure, policy practice shows marked deviation from this $[78,86]$. Different national ministries vie for the attention of large successful cities in having them register for their respective programs. Municipal governments pay lip-service to national regulations and guidelines while actually building the neighborhoods they like and submit reports of suboptimal quality to those same ministries. Project developers strike deals with officials at the district level to build these massive real estate projects, because as noted, local governments eventually depend more on the revenues derived from them than from any resources the higher tiers of government can offer them $[7,9]$.

Additionally, policy processes and policy outcomes may diverge from province to province, city to city, and district to district depending on economic opportunities, geographic position, politico-administrative culture, and the personalities of politicians and high-level officials in charge. In some parts of the country, as in the Mega City Regions Jing-Jin-Ji, Yangtze River Delta, and Pearl River Delta, we can observe the emergence of incipient regional governance structures which may over time affect implementation [8,87]. To this I should add, as stipulated elsewhere [88], that countervailing powers against the politico-administrative complex and more specifically the individuals holding key positions within the various party and government bodies and at various levels of government are weak in China. Legislative committees in China are very large, are convened infrequently and are unlikely to challenge top leaders, judges are party-members and therefore subject to party rule rather than independent, and judicial rulings do not automatically prevail over government decisions and may therefore not actually be enforced [89]. Bureaucrats working for the civil service tend to show far less boldness in taking initiatives of their own, will not offer advice contrary to what their superiors expect and/or go against wishes of higher ranked officials [90]. Consultative bodies and academic consultants also dance far more to the tunes of their political clients than in most Western countries [91]. In China's more recent political climate, citizens' activities are closely monitored under heavy surveillance in certain provinces [92], alongside with upgrading propaganda by the central Ministry of Information and Propaganda [93].

As a result, although in the Chinese party-state power is centralized in name and reputation, studies in policy-making in general and studies in sustainable urbanization policy-making in particular reveal that concentration of power would be a more suitable description of the situation $[77,94]$. While many younger representatives of the Red Families who came to power in the aftermath of the Chinese revolution still hold crucial positions in the CCP and the government now, they have been complemented by private business tycoons and the most talented among students at good universities who were invited to the party since former party leader Jiang Zemin opened the party ranks to the successful and the beautiful to generate enough critical mass for the CCP to be strong, alert, and intelligent and stay in power [95-97]. The combination of exclusive party membership, socialization, and acculturation within the party, strict top-down organized promotion systems and otherwise very weak checks and balances all lend credibility to the idea raised by Yongnian Zheng that the Chinese party-system will not become democratic any time soon [98]. Rather it uses a mixture of intricate organizational, legal practices, and Gramscian ideological approaches to stay in power by scanning through various channels for those socio-economic and political issues that are deemed important in society, then convert these into ideological and societal discourses addressing these issues and meanwhile limiting effective access to policy-making arenas to the masses of the people. If anything, Chinese party elites have gained more rather than less influence in the past few decades.

Power accumulation has shifted to those societal groups that live in the wealthy and large cities by the East coast, where a history of party loyalty has conflated with success in government, business, or leading universities in the nation and where track records of being directly or indirectly in charge of constituencies with faster than average economic growth has been recorded over the years, where major social revolt is prevented and where the ecological discourse reflected in the use of green city 
labels is convincingly vented to the outside world and helps attract and keep satisfied investors, high tech corporations, talented residents, and substantial numbers of visitors $[8,81,84]$. As in the case of capital accumulation in sustainable urbanization, the mobilization of bias promoted through power accumulation is systematic and exceeds the thresholds of pluralistic input to decision-making or even the position of a limited number of policy actors having structurally more resources in and input to the policy process $[80,94,96,99]$. The policy process begins with a discourse on ecological civilization aired by a small set of policy elites and aimed at responding to real societal problems. Along the way, however, it loses its idealistic edge, essential resources that could potentially be deployed towards making new towns more social and ecological for their inhabitants leak away and the result is very middle-of-the-road neighborhoods for which the term eco or low carbon is (mis)used in spite of ample evidence that they barely deserve the name $[6,7,100,101]$. The real game can best be understood by looking at what drives career paths of public and private powerbrokers and it is geared towards the fulfilling of the needs of a comparatively small section of the Chinese population: the loyal party elite and the prosperous business community which have increasingly merged into a single social stratum [80].

\section{Examining the Validity of a Neo-Marxist Perspective: Structural Forces behind the Mobilization of Bias?}

There is a vast literature within the field of urban studies on the process of urbanization in China. There is also quite a substantial number of publications on the organization of the Chinese political and administrative system in the disciplines of political science and public administration. Much of this is empirical in nature and covers a variety of topics giving a fairly complete account of how planning and policy for how urban and infrastructure development work in China. In the 2010s, an equally interesting set of books and articles has emerged outlining to what extent and how urban development in China can be called green or sustainable, often at the intersection of geography, planning, environmental science, politics, and public administration. Only a very limited number of authors has taken up the task of examining to what extent and how planning and policy regarding urbanization in general and sustainable urbanization in particular displays neo-Marxist features. In geography and planning David Harvey (2007), You-tien Hsing (2010), and Fulong Wu (2015) have used the term capital accumulation to qualify China's great urban transformation [68,76,102]. In politics and policy, Xiaobo Lv (2000), Bruce Dickson (2008), and Yongnian Zheng (2010) have demonstrated how the Chinese party-state is able to perpetuate its own power position through co-optation and by making successful use of policy-discourses to address perceived policy problems in the country $[94,96,98]$. None of these three influential authors have taken their analysis to imply that some form of neo-Marxism would be a fruitful way to qualify the entire process of sustainable urban and infrastructure planning and policy-making. This is admittedly a rather peculiar exercise given the fact that traditionally China is supposed to apply Marxism in its planning and policy practices rather than that some form of Marxism should be applied to the People's Republic of China.

It is true that applying traditional Marxism to China would make little sense: the nature of China's socio-economic inequality goes far beyond class struggle alone and so does the complexity of the nation's class structure [72,103]. However, if neo-Marxism is interpreted in a reformed sense by investigating where the origin behind the mobilization of bias in decision-making processes regarding sustainable urbanization can be located and whether forms of capital and power accumulation among elites can be found, the question loses none of its pertinence. In fact, it can even be answered in the affirmative: there is reason to suppose that a red political elite exists which can be seen as a structural force in the planning and decision-making of sustainable cities and is able to accumulate both capital and power.

The emergence of huge numbers of new towns in China going by the names of eco city, low carbon city, low carbon eco city, sponge city, or smart city is staggering by any account. These are all responses to the massive influx of rural migrants to city and the introduction of an 'eco-civilization' and 'new type 
urbanization' discourse by the leadership of the Chinese Communist Party. These various sustainable city labels echo the eco language promoted from among central organs in Beijing, but eventually reflect orthodoxy ('right speak') with heteropraxy (deviant practice) [104]. Lofty ambitions and policy rhetoric are watered down and amount to very regular construction projects where lust for financial gain and use of technocratic indicator systems lead attention away from mediocre physical results on the ground, even in touted international projects such Sino-Singaporean Tianjin Eco City, International Caofeidian Eco City, Shenzhen International Low Carbon City, or Chongming International Eco Island. It is as if the fervor and the resources for doing something truly sustainable and glorious leak away somewhere between national discourse and local implementation. If the found implementation gap could be explained by some policy actors winning sometimes while others win at other times without a systematic mobilization of bias, one could call such a process 'polyarchic' or pluralistic. Even if some policy actors systematically have more favorable institutional positions, but the justification for this bias could be explained by these policy actors as such rather than by the individuals or groups populating these actors, an analysis somewhere in between pluralism and elitism might have sufficed. However, what I found both in the expropriation, planning, and re-destination of land and in the control of key positions in the party state, was a structural bias in favor of party elites. These structurally dominant positions allow them to accumulate both capital and political power at the exclusion of all outside groups, while also to some extent benefiting urban residents at the expense of rural collectivities. Legal rules restricting access to land ownership and control alongside exclusionary entitlements to positions and promotion on the basis of party membership and party loyalty make it that mobilization of bias can also be seen as the result of structural forces being at work in the People's Republic of China.

The remaining question is whether the term neo-Marxism or elitism is more accurate to apply under circumstances where the political elite of the CCP holds all instruments of power and utilizes the state apparatus to its own advantage. It is obviously relevant that the drivers behind growing inequality are strong but dissimilar to the dynamics of class struggle in 19th century Europe. I have described capital accumulation through the expropriation of land rather than labor (although a case for labor exploitation could also be made). I have indicated how control is exerted at least as much through the state apparatus as it is through ownership of the means of production. Elites here and now are not industrial capitalists in the private sector, but influential CCP members and their allies controlling a variety of instruments including land, capital, means of production, knowledge and legal and organizational powers extend to both the public and private sectors $[80,96]$. Add to this that the current use of the Chinese 'hukou' system encourages rural migrants to offer cheap labor services in cities while being restricted from valuable public services present in these same prosperous cities, the inclination of especially first-tier cities such as Beijing, Shanghai, Guangzhou, and Shenzhen to severely restrict legally valid migration to their territories and the trend of leading cities such as Beijing to relocate its polluting industries to poorer provinces around it such as Hebei or even further inland, and a picture of structural and rapidly growing inequality in many senses of the word inevitably appears.

It requires well-reflected and thorough input from theory pundits in neo-Marxism to provide an accurate label for my findings. The mechanisms and processes laid bare in this contribution are based on an abstract and high-level interpretation of ample existing empirical evidence on the planning and politics of sustainable urbanization in China. This theoretical generalization now requires a more systematic and deductive methodological test and (to the extent possible) confirmation through the collection of extensive numerical data on financial flows and control of key positions and/or detailed field studies mapping where and how blockages in the implementation appear and where benefits and losses travel in this process. At this point, however, I believe I have provided a credible account of the structural dynamics leading to the discordance between an impressive central-level discourse on ecological civilization and rather unimpressive new town results on the ground. Marx seems resuscitated again in a different guise, around the world and apparently also in the People's Republic of China. 
Funding: This research received support from the Erasmus Initiative for the Dynamics of Inclusive Prosperity (DoIP).

Acknowledgments: The author is indebted to Byron Murphy, guest-editor Ari-Veikko Anttiroiko, and three anonymous reviewers for valuable comments to an earlier version of this paper.

Conflicts of Interest: The author declares no conflict of interest.

\section{References}

1. United Nations Environment Programme (UNEP). UN Environment 2016 Annual Report; United Nations Publications: Herndon, VA, USA, 2016.

2. Girardot, N.J.; Miller, J.; Liu, X. Daoism and Ecology: Ways within a Cosmic Landscape; Harvard University Press: Cambridge, MA, USA, 2001.

3. United Nations Environment Programme (UNEP). Green Is Gold: The Strategy and Actions of China's Ecological Civilization; United Nations Publications: Herndon, VA, USA, 2016.

4. Li, H.; de Jong, M. Citizen participation in China's eco-city development. Will 'new-type urbanization' generate a breakthrough in realizing it? J. Clean. Prod. 2017, 162, 1085-1094. [CrossRef]

5. Chen, M.; Liu, W.; Lu, D. Challenges and the way forward in China's new-type urbanization. Land Use Policy 2016, 55, 334-339. [CrossRef]

6. Caprotti, F. Critical research on eco-cities? A walk through the Sino-Singapore Tianjin Eco-City, China. Cities 2014, 36, 10-17. [CrossRef]

7. De Jong, M.; Yu, C.; Joss, S.; Wennersten, R.; Yu, L.; Zhang, X.; Ma, X. Eco city development in China: Addressing the policy implementation challenge. J. Clean. Prod. 2016, 134,31-41. [CrossRef]

8. De Jong, M.; Chen, Y.; Joss, S.; Lu, H.; Zhao, M.; Yang, Q.; Zhang, C. Explaining city branding practices in China's three mega-city regions: The role of ecological modernization. J. Clean. Prod. 2018, 179, 527-543. [CrossRef]

9. Lu, H.; de Jong, M.; ten Heuvelhof, E. Explaining the variety in smart eco city development in China-What policy network theory can teach us about overcoming barriers in implementation? J. Clean. Prod. 2018, 196, 135-149. [CrossRef]

10. Van Bueren, E. Greening Governance: An Evolutionary Approach to Policy Making for a Sustainable Built Environment; IOS Press/Delft University Press: Amsterdam, The Netherlands, 2009; ISBN 9781607500780.

11. Klijn, E.H.; Koppenjan, J. Governance Networks in the Public Sector; Routledge: London, UK; New York, NY, USA, 2016.

12. Zheng, H.; De Jong, M.; Koppenjan, J. Applying policy network theory to policy-making in China: The case of urban health insurance reform. Public Admin. 2010, 88, 398-417. [CrossRef]

13. Mu, R.; de Jong, M.; Koppenjan, J. Assessing and explaining interagency collaboration performance: A comparative case study of local governments in China. Public Manag. Rev. 2019, 21, 581-605. [CrossRef]

14. Cairney, P. Understanding Public Policy: Theories and Issues (Textbooks in Policy Studies); Palgrave Macmillan: Basingstoke, UK, 2011.

15. Schattschneider, E.E. The Semisovereign People: A Realist's View of Democracy in America; Rinehart and Winston: Holt, MI, USA, 1965.

16. Lindblom, C.E. Politics and Markets: The World's Political-Economic System; Basic Books: New York, NY, USA, 1977.

17. Lindblom, C.E.; Dahl, R.A. Politics, Economics, and Welfare: planning and Politico-Economic Systems Resolved into Basic Social Processes; University of Chicago Press: Chicago, IL, USA, 1976.

18. Poulantzas, N.A. State, Power, Socialism; Camiller, P., Ed.; Verso: London, UK, 1980.

19. Dahl, R.A. Polyarchy: Participation and Opposition; Yale University Press: New Haven, CT, USA, 1971.

20. Barrow, C.W. Critical Theories of the State: Marxist, Neomarxist, Postmarxist; University of Wisconsin Press: Madison, WI, USA, 1993.

21. Flint, C.; Taylor, P.J. Political Geogr. World-Economy, Nation-State and Locality; Routledge: New York, NY, USA, 2018.

22. Das, R.J. Marxist theories of the state. In Alternative Theories of the State; Palgrave Macmillan: New York, NY, USA, 2006; pp. 64-90. 
23. Anttiroiko, A.-V. The Political Economy of City Branding; Routledge: New York, NY, USA, 2014; ISBN 9780203782187.

24. Berg, P.O.; Björner, E. Branding Chinese Mega-Cities: Policies, Practices and Positioning; Edward Elgar Publishing: Cheltenham, UK, 2014.

25. Baker, B. Place Branding for Small Cities, Regions and Downtowns: The Essentials for Successful Destinations; Independently Published: Traverse, MI, USA, 2019; ISBN 1098740904.

26. People.cn. The Key Term of Ecological Civilization at the 17th National Congress of CPC. Available online: http://cpc.people.com.cn/GB/104019/105389/6424940.html (accessed on 25 May 2019).

27. XinhuaNet. Proposed Amendment to CPCCC Charter Unveiledof the CPC Charter at the 18th National Congress of CPC. 2012. Available online: http://www.xinhuanet.com/english/2018-03/08/c_137025376.htm (accessed on 26 September 2019).

28. Central Committee (CPC) \& State Council. State Council Integrated Reform Plan for Promoting Ecological Progress; Central Committee (CPC) \& State Council: Beijing, China, 2015.

29. NDRC. The 13th Five-Year Plan for Economic and Social Development of the People'S Republic of China; National Development and Reform Commission: Beijing, China, 2016.

30. Xinhua News Agency the Report at the 19th National Congress of the Communist Party of China by Xi Jinping. Xinhua News Agency, 18 October 2017; 66.

31. Chinadaily Constitutional Revision to Help Build Beautiful China. Available online: http://www.chinadaily. com.cn/a/201803/12/WS5aa5bd4aa3106e7dcc140ec4.html (accessed on 25 May 2019).

32. Xinhua News China's Urbanization Rate Reached 58.52\%. Xinhua News Agency, 3 May 2018.

33. State Council of the People's Republic of China. State Council China Unveils Landmark Urbanization Plan; State Council of the People's Republic of China: Beijing, China, 2014.

34. Shen, Q. Study on new-type urbanization based on Ecological civilization. Urban Plan. Forum 2013, 1, 29-36. (In Chinese)

35. Yu, L. The discussion on ecological civilization and new type urbanization in China. Urban Dev. Stud. 2016, 23, 19-26. (In Chinese)

36. Zhuang, T.; Qian, Q.K.; Visscher, H.J.; Elsinga, M.G.; Wu, W. The role of stakeholders and their participation network in decision-making of urban renewal in China: The case of Chongqing. Cities 2019, 92, 47-58. [CrossRef]

37. Chen, Y.; Zhu, D.; Zhou, L. A game theory analysis of promoting the spongy city construction at the building and community scale. Habitat Int. 2019, 86, 91-100. [CrossRef]

38. Caprotti, F.; Springer, C.; Harmer, N. "Eco" For Whom? Envisioning Eco-urbanism in the Sino-Singapore Tianjin Eco-city, China. Int. J. Urban Reg. Res. 2015, 39, 495-517. [CrossRef]

39. Chan, F.K.S.; Griffiths, J.A.; Higgitt, D.; Xu, S.; Zhu, F.; Tang, Y.T.; Xu, Y.; Thorne, C.R. "Sponge City" in China-A breakthrough of planning and flood risk management in the urban context. Land Use Policy 2018, 76, 772-778. [CrossRef]

40. Fu, Y.; Zhang, X. Planning for sustainable cities? A comparative content analysis of the master plans of eco, low-carbon and conventional new towns in China. Habitat Int. 2017, 63, 55-66. [CrossRef]

41. Wu, Z.; Tang, J.; Wang, D. Low Carbon Urban Transitioning in Shenzhen: A Multi-Level Environmental Governance Perspective. Sustainability 2016, 8, 720. [CrossRef]

42. Wu, Y.; Zhang, W.; Shen, J.; Mo, Z.; Peng, Y. Smart city with Chinese characteristics against the background of big data: Idea, action and risk. J. Clean. Prod. 2018, 173, 60-66. [CrossRef]

43. Yu, L. Low carbon eco-city: New approach for Chinese urbanisation. Habitat Int. 2014, 44, 102-110. [CrossRef]

44. Yu, C.; Dijkema, G.P.J.; De Jong, M.; Shi, H. From an eco-industrial park towards an eco-city: A case study in Suzhou, China. J. Clean. Prod. 2015, 102, 264-274. [CrossRef]

45. Cheshmehzangi, A.; Xie, L.; Tan-Mullins, M. The role of international actors in low-carbon transitions of Shenzhen's International Low Carbon City in China. Cities 2018, 74, 64-74. [CrossRef]

46. Xie, L.; Flynn, A.; Tan-Mullins, M.; Cheshmehzangi, A. The making and remaking of ecological space in China: The political ecology of Chongming Eco-Island. Political Geogr. 2019, 69, 89-102. [CrossRef]

47. Liu, C. China's City of the Future Rises on a Wasteland. Scientific American, 28 September 2011.

48. De Jong, M.; Joss, S.; Schraven, D.; Zhan, C.; Weijnen, M. Sustainable-smart-resilient-low carbon-eco-knowledge cities; making sense of a multitude of concepts promoting sustainable urbanization. J. Clean. Prod. 2015, 109, 25-38. [CrossRef] 
49. Fu, Y.; Zhang, X. Trajectory of urban sustainability concepts: A 35-year bibliometric analysis. Cities 2017, 60, 113-123. [CrossRef]

50. Li, Y.; Qiu, L. A comparative study on the quality of China's eco-city: Suzhou vs Kitakyushu. Habitat Int. 2015, 50, 57-64. [CrossRef]

51. Lin, Z. Ecological urbanism in East Asia: A comparative assessment of two eco-cities in Japan and China. Landsc. Urban Plan. 2018, 179, 90-102. [CrossRef]

52. Liu, H.; Zhou, G.; Wennersten, R.; Frostell, B. Analysis of sustainable urban development approaches in China. Habitat Int. 2014, 41, 24-32. [CrossRef]

53. Register, R. Eco-Cities: Rebuilding Cities in Balance with Nature; New Society: New Gabriola, BC, Canada, 2006.

54. De Jong, M.; Wang, D.; Yu, C. Exploring the Relevance of the Eco-City Concept in China: The Case of Shenzhen Sino-Dutch Low Carbon City. J. Urban Technol. 2013, 20, 95-113. [CrossRef]

55. Ma, X.; de Jong, M.; den Hartog, H. Assessing the implementation of the Chongming Eco Island policy: What a broad planning evaluation framework tells more than technocratic indicator systems. J. Clean. Prod. 2018, 172, 872-886. [CrossRef]

56. De Jong, M.; Hoppe, T.; Noori, N. City Branding, Sustainable Urban Development and the Rentier State. How Do Qatar, Abu Dhabi and Dubai Present Themselves in the Age of Post Oil and Global Warming? Energies 2019, 12, 1657. [CrossRef]

57. Ren, X. Urban China; Polity Press: Cambridge, UK, 2013.

58. Yusuf, S.; Nabeshima, K.; Perkins, D.H. Under New Ownership: Privatizing China's State-Owned Enterprises; Stanford University Press/World Bank: Washington, DC, USA, 2006.

59. Deng, W.; Cheshmehzangi, A. Eco-Development in China: Cities, Communities and Buildings; Palgrave Macmillan: Basingstoke, UK, 2018.

60. Wu, W.; Gaubatz, P.R. The Chinese City; Routledge: London, UK, 2013.

61. Miller, T. China's Urban Billion: The Story behind the Biggest Migration in Human History; Zed Books: London, UK, 2012.

62. Shepard, W. Ghost Cities of China: The Story of Cities without People in the World's Most Populated Country; Zed Books: London, UK, 2015.

63. Jain-Chandra, S.; Khor, N.; Mano, R.; Schauer, J.; Wingender, P.; Zhuang, J. Inequality in China-Trends, Drivers and Policy Remedies. IMF Work. Pap. 2018, 18, 1. [CrossRef]

64. Sun, L.; Ho, P. Formalizing informal homes, a bad idea: The credibility thesis applied to China's "extra-legal" housing. Land Use Policy 2018, 79, 891-901. [CrossRef]

65. Wang, J.; Liu, Z. The problem on city, land and housing issues (Chinese). In Annual Report on the Development of China's New Urbanization; Social Sciences Acdemic Press (China): Beijing, China, 2014; pp. 55-70. ISBN 978-7-5097-6600-2.

66. Lin, G.C.S.; Zhang, A.Y. Emerging spaces of neoliberal urbanism in China: Land commodification, municipal finance and local economic growth in prefecture-level cities. Urban Stud. 2015, 52, 2774-2798. [CrossRef]

67. Friedmann, J. China's Urban Transition; University of Minnesota Press: Minneapolis, MN, USA, 2005.

68. Wu, F. Planning for Growth:Urban and Regional Planning in China; Upton, R., Grant, J., Ward, S., Eds.; First; Routledge: New York, NY, USA, 2015; ISBN 9780415814416.

69. Tsang, A. Off the charts: Beijing family fortunes. Financial Times, 11 July 2012.

70. Forsythe, M. Wang Jianlin, a Billionaire at the Intersection of Business and Power in China. The New York Times, 28 April 2015.

71. Xu, Q. Real Estate Market Is Monopolized by Power Economy (Chinese). Finance.Sina. 2006. Available online: https://bj.leju.com/news/2006-12-04/0814163099.html (accessed on 26 September 2019).

72. Ren, H. The Middle Class in Neoliberal China: Governing Risk, Life-Building, and Themed Spaces; Routledge: New York, NY, USA, 2013.

73. Sun, L.; Liu, T. Injured but not Entitled to Legal Insurance Compensation-Ornamental Institutions and Migrant Workers' Informal Channels in China. Soc. Policy Admin. 2014, 48, 905-922. [CrossRef]

74. Sun, L.; Liu, T. Occupational diseases and migrant workers compensation claiming in China: An unheeded social risk in asymmetrical employment relationships. Health Sociol. Rev. 2016, 25, 122-136. [CrossRef]

75. Chen, A. The Impact of Land Requisition on Peasant Life in China. Mod. China 2019. [CrossRef]

76. Hsing, Y. The Great Urban Transformation; Oxford University Press: Oxford, UK, 2010; ISBN 9780199568048.

77. Joseph, W.A. Politics in China: An Introduction; Oxford University Press: Oxford, UK, 2010. 
78. Lieberthal, K. Governing China: From Revolution Through Reform; W.W. Norton: New York, NY, USA, 2004.

79. Shambaugh, D.L. China's Communist Party: Atrophy and Adaptation; University of California Press: Berkeley, CA, USA, 2008.

80. Callick, R. The Party Forever: Inside China's Modern Communist Elite; Palgrave Macmillan: Basingstoke, UK, 2013.

81. Landry, P.F. Decentralized Authoritarianism in China: The Communist Party's Control of Local Elites in the Post-Mao Era; Cambridge University Press: Cambridge, UK, 2008.

82. Opper, S.; Nee, V.; Brehm, S. Homophily in the career mobility of China's political elite. Soc. Sci. Res. 2015, 54, 332-352. [CrossRef]

83. Shih, V.; Adolph, C.; Liu, M. Getting Ahead in the Communist Party: Explaining the Advancement of Central Committee Members in China. Am. Political Sci. Rev. 2012, 106, 166-187. [CrossRef]

84. Li, Y. Governing Environmental Conflicts in China; Routledge: New York, NY, USA, 2018.

85. Liu, L.; Wu, T.; Li, S.; de Jong, M.; Sun, Y. The drivers of local environmental policy in China: An analysis of Shenzhen's environmental performance management system, 2007-2015. J. Clean. Prod. 2017, 165, 656-666. [CrossRef]

86. Saich, T. Governance and Politics of China; Palgrave Macmillan: New York, NY, USA, 2004.

87. Lu, H.; de Jong, M.; Song, Y.; Zhao, M. Establishing Regional Brand Identities for Mega City Regions in China-A Multi-Level Governance Perspective. Under review.

88. De Jong, M.; Stout, H.; Sun, L. Seeing the people's Republic of China through the eyes of montesquieu: Why Sino-European collaboration on eco city development suffers from European misinterpretations of "good governance". Sustainability 2017, 9, 151. [CrossRef]

89. Forsythe, M. China's Chief Justice Rejects an Independent Judiciary, and Reformers Wince. The New York Times, 18 January 2017.

90. Lin, J. An Institutional Analysis of China's “Urban Disease” (Chinese literature). Urban Plan. Forum 2012, 201, 16-22.

91. Buckley, C. A Chinese Law Professor Criticized Xi. Now He's Been Suspended. The New York Times, 26 March 2019.

92. Buckley, C.; Mozur, P. How China Uses High-Tech Surveillance to Subdue Minorities. The New York Times, 24 May 2019.

93. Creemers, R. Cyber China: Upgrading propaganda, public opinion work and social management for the twenty-first century. J. Contemp. China 2017, 26, 85-100. [CrossRef]

94. Lü, X. Cadres and Corruption: The Organizational Involution of the Chinese Communist Party; Stanford University Press: Stanford, CA, USA, 2000.

95. Holbig, H. The Party and Private Entrepreneurs in the PRC. Cph. J. Asian Stud. 2002, 16, 30-56. [CrossRef]

96. Dickson, B.J. Wealth Into Power: The Communist Party's Embrace of China's Private Sector; Cambridge University Press: Cambridge, UK, 2008.

97. Mc Gregor, R. The Party: The Secret World of China's Communist Rulers; Penguin: London, UK, 2010.

98. Zheng, Y. The Chinese Communist Party as Organizational Emperor: Culture, Reproduction, and Transformation; Routledge: New York, NY, USA, 2010.

99. Elizabeth, V.W.D. Ruling, Resources and Religion in China: Managing the Multiethnic State in the 21st Century; Palgrave Macmillan: Basingstoke, UK, 2013.

100. Caprotti, F. Eco-urbanism and the eco-city, or, denying the right to the city? Antipode 2014, 46, 1285-1303. [CrossRef]

101. Caprotti, F. Eco-Cities and the Transition to Low Carbon Economies; Palgrave Macmillan: London, UK, 2014.

102. Harvey, D. A Brief History of Neoliberalism; Oxford University Press: Oxford, UK, 2007.

103. Goodman, D.S.G. Class in Contemporary China; Polity Press: Cambridge, UK, 2014.

104. Jullien, F. Detour and Access: Strategies of Meaning in China and Greece; Zone Books: Cambridge, MA, USA, 2000. 